\title{
African Constitutions in the Context of Democracy, Human Rights, Peace and Development
}

\author{
Cons Matata ${ }^{1}$ \\ ${ }^{1}$ Hekima University College, Institute of Peace Studies and International Relations, Nairobi, Kenya
}

\begin{abstract}
African countries that observe democracy and human rights tend to be stable and are recording rapid economic growth. On the other hand, African countries which have reneged on democracy by banning open democratic competitions, changed the constitutional provisions to prolong their leaders' hold on power and do not observance human rights, are experiencing decline in economic growth. Violence and civil strife also tend to follow where freedom of expression or assembly is curtailed and the provisions of the bill of rights are being violated. Sensible economic policies such as the liberalised market too are contributing to growth compared to countries such as Zimbabwe and Eritrea where the reverse is taking place. Peaceful resolution of conflicts which has since taken a hold in Africa is also promoting economic growth. Focus on the marginalised, women and people with disability are the other factors spurring growth. Devolved units of government such as is being practiced in Nigeria, Kenya, Namibia and many other African countries not only help to distribute wealth evenly among the people but has also served as a means of mobilizing human resources as regards labour and skills.
\end{abstract}

Keywords: constitution, democracy, development, growth

\section{INTRODUCTION}

Kenya is a nation of many ethnic groups. The current constitution lists 42 ethnic groups with distinct languages, cultures and geographical boundaries. Before colonialism these ethnic groups coexisted and roamed the land depending on need, for example hostile neighbours, inadequate pasture due to population pressure, inter-communal cattle theft, and disease outbreaks such as anthrax, tsetse flies, smallpox, etc. Drought and other natural disasters were also frequent causes of mass migration. When the colonialists came, their spheres of influence were not based on ethnicity or nationalities but on latitudes and longitudes. Thus, when Kenya was declared a British protectorate in 1895, the name itself was a corrupted form of the name of a mountain which stood on only a fraction of one ethnic group's land - Mount Kirinyaga which later became known as Mount Kenya.

The latitudes and longitudes-based boundaries meant that many people who could have naturally been within the boundaries of Kenya such as the Masaai, the Kuria, the Turkana, the Luo, the Samia, the Turkana, the Somali and many others found themselves scattered across several countries and under different colonial administrators such as the Germans, the French, the Belgians, and the Anglo-Egypt Sudan. The colonial administrators introduced laws and regulations applicable in their countries including rules regarding administrations and the creation of the upper, middle and lower classes. The lords were the governors, who sat in parliament, owned large tracts of land and served as ministers, the "Sirs" were judges, provincial governors, etc., and the "misters" were the local administrators. Residential areas were also classified in a similar manner: high class areas for the peerage class, the white middle class area, the Asian quarters and at the lowest bottom, the African quarters.

It was only at independence that the constitutions were introduced or the so-called independence constitution for the newly independent countries. For former British colonies, these were based on the Lancaster Model and naturally followed the British class system: lords or the elites, the middle and the lower classes. This resulted in the uneven development which followed after independence. Some areas were completely ignored in matters of development.

The new African leaders followed the colonial models, with many declaring themselves or having been declared lords or sirs by the departing colonial authorities; Sir Seretse Khama of Botswana, Sir Edward Mutesa of Uganda, Sir Nnamdi Azikiwe of Nigeria, Lord Delamere of Kenya, etc. They inherited the huge mansions and large tracks of land left behind by the former colonial masters. They too like the colonial governors resorted to rule by decrees. Rule through decrees meant that even the semblance of checks and balances created by the Lancaster constitution were soon discarded. For example, the Lancaster Constitution of Kenya provided for protection of the minority ethnic groups in a federalist or "majimbo" system, but the decentralized system was soon abandoned in favour of a republican system with centralized power in the presidency; even the presidency was soon construed as an individual occupying that office. The multi-party system too was abolished and in 
most cases the opposition politicians were either sent to jail or into exile. The newly created post of the president, formerly the office of the prime minister in the Lancaster constitution, became, for all intents and purposes, a dictatorial office or an "absolute ruler" [1].

However, unlike the current breed of African constitutions, the independence constitution did not provide for, or considered very flippantly, the socio-economic rights of the varied ethnic groups within a country. These "socio-economic rights are ethico-political claims to employment, social security, health, education and adequate living standards" [2]. These soon became the main issues after the independence of African countries. In many African countries, the political elite who took over from the colonialists were accused of politics of divide and rule (just like the colonialists) and widespread nepotism. This led to marginalisation of large sections of populations, which in turn, gave rise to civil wars such as the Shifta uprising in Kenya.

The Kenyan Somali, feeling marginalized, revolted against the Kenyatta government in an attempt to secede from Kenya and join their fellow Somali, in Somalia. Many were killed, not only under Kenyatta's reign but also under his successor, Daniel Arap Moi. The worst incident of the uprising occurred "in 1984, when a military operation to disarm members of the Somali Degodia clan led to the seizure of more than 5,000 men who were assembled at the Wagalla Airstrip in Wajir District in NFD (Northern Frontier District). After brutal beatings and torture, more than 3,000 were murdered and many more maimed in what became known as the Wagalla Massacre. The United Nations later described the incident as "the worst human rights abuse in Kenya's history" [3].

Wagalla was not the end of such phenomenon. The clamour against marginalisation and inequality continued unabated. The expressions for equality manifested themselves in the infamous election violence incidents in Kenya which took place during every election; in 1988, 1992, 1997, 2002 and the better known 2007/8 post-election violence. Each time the violence was either instigated by, or directed against the ethnic groups that claimed marginalisation by successive governments. Even what the foreign press dubbed as "peaceful" Kenyan elections in 2013, the local population described it as one of "tense calm" or "unstable peace" [4]. However, as shall be described in later section, "the unstable peace", was a big departure from the usual death, rape, destruction of property and displacement that had become the norm in every election in Kenya.

Kenya's case was not exceptional. From the 1970s to mid-1990s a similar situation was being replicated in Uganda, Nigeria, Mozambique, Angola, The Democratic Republic of Congo (DRC) and other African countries. In the late 1960s, the then Ugandan Prime Minister declared himself as an executive president and made the country a republic. The constitution writing was a one person affair. The president only informed the members of parliament that they would find the new constitution "in your pigeon holes" [5]. By this time nearly all African countries were either one party states, or military dictatorships. Indeed Article 2A of the then Kenyan constitution stated that there would only be one party in Kenya, the ruling party, known as the Kenya African National Union (KANU). Article 2A was only removed after violent protests which resulted in many deaths, thousands of injuries and the cancellation of aid to the country by the Scandinavian countries and other western countries such as the USA and the UK [6].

In African political economy, this period (1980-2000) became famously known as the "Lost Decades" [7]. It was characterised by negative growth, capital flight, little Foreign Direct Investment, aid dependency, brain drain, civil wars, military coups and many other negative events. This is contrary to the current period, characterised by high and sustained growth, which has since been declared "Africa's Moment" [8], "Emerging Africa" [9] or "Africa Rising" [10]. Some African countries such as Ethiopia, Tanzania, Botswana and Benin are recording near or double digit growth rates. Africa itself, despite many challenges from some of its members such as Somalia, Burundi and South Sudan, is recording an average growth 6\%-higher than Europe, the Americas and much of Asia including Japan [10].

Foreign aid too is being replaced by Foreign Direct Investment. Indeed FDI has been rising since 2000. Instead of loans, Africa is now floating bonds, such as the Eurobond.. Such is the high confidence in Africa that the recent Eurobond floats by Kenya and Cote d'Voire were oversubscribed. The brain drain is now replaced by Diaspora remittances which amount to billions of dollars annually. In most African countries Diaspora remittances are only second to Agriculture. In Kenya and Uganda tourism was previously ranked second after agriculture. This has since been overtaken by Diaspora remittances. While in the 1970s and 80s an African relocating from his or her country to Europe or America was considered a traitor or an enemy of the state for example, Ngugi wa Thiongo and Ali Mazrui, now he/she is considered foresighted. Not only are his/her remittances important to the country, but also the skills gained outside the country. Some of these Africans have since returned home to set up innovative firms in the areas of energy, communication, IT and many others. Mpesa money remittance and several e-pay mobile and computer applications are such innovations gained from outside Africa but modified to work in the African situation. Africa's "emerging" or "rising" has however, not happened in a vacuum, due to several factors. Key to these factors are the new constitutions which introduced 
democracy. From 2000 onwards, most of Africa began to open up. Single party dictatorship constitutions were amended to give room for multi-party democracy. This started with the amendment of Section 2A in Kenya which restricted participation in any other political party apart from KANU. Tanzania also did away with restrictions on political participation which previously was a preserve of the Chama Cha Mapinduzi (Revolutionary Party). Zambia, Malawi, Uganda, and other African countries also followed suit. Although some countries such as Ethiopia resisted a complete opening up, some political space was nevertheless opened to the population. Some countries such as Kenya went even further, entrenching multiparty democracy in the constitution (cf: Article 4 (2) of the Constitution of Kenya). At the same time nearly all of Africa with the exception of the Spanish Sahara (Saharawi Arab Democratic Republic), attained full independence or majority rule, such as South Africa in 1994 and Namibia in 1989. Africa's civil wars too, more or less came to an end in this period; Mozambique, Uganda, Rwanda, Burundi, Sudan, Angola, etc.

The African countries that continue to adhere to the democratic constitutions and generally uphold the rule of law such as Tanzania, Kenya, Benin and Cote d'Voire among others, continue to prosper. On the other hand, those that have reneged or are going back to the old dark days such as Rwanda, the Republic of Congo, Eritrea and the DRC etc., have started to lose on growth.

It can now be safely advanced that the turnaround in African countries is as a result of "...the rise of more democratic and accountable governments and the introduction of more sensible economic policies" [9]. It can therefore be said that democratic and constitutional guarantees or the dispensations of the two directly affect economic growth. In a country such as Kenya or Tanzania where the constitution provides for accountability, a free and open economy and people's participation, the economy tends to grow faster. At the time of publishing his book, all the seventeen countries listed by Radelet [9], practiced democracy in one form or another and all of them recorded impressive growth. Some of them - Tanzania, South Africa, Ethiopia, Botswana - continue to record impressive growth. Uganda's growth, on the other hand, stalled when it started to renege on democracy such as the introduction of the presidential term limits and unilateral interventions on regional conflicts such as in the DRC and South Sudan.

Following the introduction of devolution in Kenya through the 2010 Constitution in which devolved counties are allowed to run their affairs rather than being dictated to by the central government, there has been rapid growth especially in infrastructure, particularly transport and communication systems. County governments have been able to tarmac roads, build hospitals, set up milk collection points and cooling plants, and generally promote agriculture, tourism and investments. The devolved units also mean that the areas which were once marginalised such as the North Frontier Province, can now feel included as the leadership is local and decisions affecting the region are made at the local level rather than by the Central Government in Nairobi. These formerly marginalised areas also get the lion's share in revenue allocations. The revenue allocations are deliberately tilted in their favour in order to help them catch up with the rest of the country. For example, after over 50 years of independence from the British, some parts of Kenya such as Garissa, Wajir and Turkana only saw the first tarmac roads in 2015, that is, after the promulgation of the new constitution. Peace too is blossoming, most of the formerly marginalised areas suffered from rampant banditry, cattle rustling and poaching of wildlife. The devolved units are now able to negotiate and agree for peace amongst themselves rather than waiting for decrees from the central government. The devolved units are also better equipped to handle local conflicts than the central government located far away in the capital city, and in most cases does not have officials who speak local dialects. The devolved units are also a source of mobilization of skills and other human resources.

The African constitutions (Africa South of the Sahara) made since the mid-1990s have elaborate safeguards of human rights and participations in the form of entrenched bills of rights. The new constitutions also mean that both internal and external conflicts are settled through negotiations and compromises rather than prolonged inter-state wars and conflict such as was the case with Nigeria and Cameroon, Ethiopia and Eritrea, Rwanda and the DRC, Uganda and Sudan. Twenty or so years ago Tanzania and Malawi would have gone to war over Lake Malawi rather than have the matter amicably resolved. Burundi too would have long ago resorted to civil conflict without the intervention of other African nations. Tanzania's involvement in the Ugandan civil conflict on the side of the rebels in 1979/80 was widely condemned by most African countries. Such interventions, as in Somalia and the recent African Union Resolution on Burundi, are now being sanctioned by none other than the African Union. The right to protect and maintain democracy and the respect of human rights are now entrenched in the African system of governance and Africa shall therefore continue to rise.

However, while it is evident that better and inclusive constitutions and democracy have led to Africa's economic growth, some scholars disagree. They argue that Africa remains looted [11], [12], [13], [14]; that Africa's resources and wealth are being taken out of Africa [15], [16]; that Africa is neither moving backward nor forward; and that no one takes the continent seriously. While all these scholars are right to a certain degree, the idea of an emerging or rising Africa appears to be prevailing. Democratic ideals or space too appears to lend credence to positive economic impacts where the same is being applied. For example, the president of Benin 
recently announced his full support and respect of the country's constitution and since then, Benin's economy appears to have picked up. President Macky Sall of Senegal also recently announced voluntary reduction of the presidential term from two seven-year terms, to two five-year terms, and the country's economy appears to be growing. President Sirleaf of Liberia, whose economy has been doing well save for the outbreak of Ebola, also announced reduction of the presidential term limit from two six-year terms to two four-year terms.

The reverse, however, is true in Burundi, Rwanda, Uganda, South Sudan, Eritrea, Zimbabwe and other African countries where the leaders have refused to relinquish power. In all these countries, tensions are rising. In Burundi it is nearly open war with tens of people being murdered every day. In the DRC, where the president has been manoeuvring his way into a "third term" in office, there has been sporadic violence, while in the neighbouring Congo Republic many people have also lost their lives over the unilateral move by the current president to extend his term of office. In Cameroon, where the president has remained in office for over thirty years, economic growth is at a standstill. The same is true with Zimbabwe and Uganda where the leaders have stayed in power since 1980 and 1986 respectively.

\section{REFERENCES}

[1]. Nyinguro, P. O., \& Otenyo, E. E. (2007). Social Movements and Democratic Transitions in Kenya. Journal of Asian and African Studies, Vol 42(1): 5-24. DOI: 10.1177/0021909606072623

[2]. Murray, T. (2015). Socio-Economic Rights Versus Social Revolution Constitution Making in Germany, Mexico and Ireland, 19171923. Social \& Legal Studies, 24(4) 487-508. DOI: 10.1177/0964663915578186

[3]. Samora, M. (2013). World Policy Journal, 99-106.

[4]. Elder, C., Stigant, S., \& Claes, J. (2014). Elections and Violent Conflict in Kenya. Washinton, DC: United States Institute of Peace.

[5]. Opiyo, N., Bainomugisha, A., \& Ntambirweki, B. (2013). Breaking the conflict trap in Uganda:Proposals for Constitutional and Legal Reforms. Retrieved from Acode Uganda: http://www.acode-u.org/documents/PRS_58.pdf

[6]. Stokke, O. (Ed.). (1995). Aid and Political Conditionality. London: Frank Cass.

[7]. Onuoha, G. (2015). Arising Africa' in a resource-rich context:Change, continuity and implications for development. Current Sociology, 1-16.

[8]. Severino, J.-M., \& Ray, O. (2011). Africa's Moment. Cambridge, UK and Malden,MA, USA: Polity Press.

[9]. Radelet, S. (2010). Emerging Africa: How 17 countries are leading the way. Baltimore, Brookings Institution Press.

[10]. Economist, T. (2011, December 3). The Economist. Retrieved from The Economist Web Site: http://www.economist.com/node/ 21541015

[11]. Bond, P. (2007, January 25-27). Macroeconomic 'Superexploitation': The African Case. Retrieved from networkideas.org: http://www.networkideas.org/feathm/mar2007/PDF/Patrick_Bond.pdf

[12]. Bond, P.(2008). The Looting of Africa. Retrieved from bibliotecavirtual.clacso.org.ar: http://bibliotecavirtual.clacso.org. ar/ar/libros/sursur/lech/07bond.pdf

[13]. Burgis, T. (2015). The Looting Machine. New York: Public Affairs.

[14]. Tandon, Y. (2015). Trade Is War. Dar es Salaam, London and New York: OR Books.

[15]. Revero, O. D. (2001). The Myth of Development. London: Zed.

[16]. Olutayo, A. O., \& Omobowale, A. O. (2007). Capitalism, Globalisation and the Underdevelopment Process in Africa: History in Perpetuity. Africa Development, pp. 97-112. 